\title{
PRODUCTIVITY OF WINTER TRITICALE DEPENDING ON TYPE OF TILLAGE IN CROP ROTATION
}

\author{
Boguslawa Jaskiewicz $^{1}$, Jerzy Grabinski ${ }^{1}$, Ireneusz Ochmian ${ }^{2}$ \\ ${ }^{1}$ Institute of Soil Science and Plant Cultivation State Research Institute in Pulawy, Poland; \\ ${ }^{2}$ West Pomeranian University of Technology, Poland \\ kos@iung.pulawy.pl
}

\begin{abstract}
In recent years, cereals have been increasingly grown in simplified crop rotations. The aim of the study was to determine the grain yield of winter triticale cultivars Cerber, Alekto and Fredro under plow or plowless tillage systems and different crop rotations. A three-year study was conducted at the Experimental Station of Soil Science and Plant Cultivation State Research Institute in Puławy, Poland. The yield of winter triticale depended on the weather conditions, crop rotations, method of tillage, and genetic factor. Under optimal rainfall, higher yields of winter triticale grain were obtained under ploughing. The grain yield was higher by $15 \%$ compared to the simplified cultivation. In the crop rotation with a small percentage of cereals, the highest level of triticale yields was recorded, while lower triticale yields were obtained in the crop rotation with a large percentage of cereals. In plough cultivation conditions cvs. Cerber and Alekto showed higher yields (8.31 and $\left.6.78 \mathrm{t} \cdot \mathrm{ha}^{-1}\right)$, whereas in simplified cultivation lower grain yield was $\left(6.09 \mathrm{t} \cdot \mathrm{ha}^{-1}\right) \mathrm{cv}$.Fredro. Grain monoculture contributed to lowering the level of winter triticale yield.
\end{abstract}

Keywords: reduced cultivation, soil, triticale, yields.

\section{Introduction}

In recent years, cereals have been increasingly grown in simplified crop rotations. Farmers have opted for these changes due to economic, organizational, and environmental reasons [1-3]. In German experiments, triticale yielded similarly after traditional and simplified tillage, whereas the species yielded highest, when direct sowing was used [4]. In the study of other authors [5;6] triticale yields were lower under simplified cultivation conditions. Cereal cultivars respond differently to changes in environmental conditions, including the method of the soil cultivation. In the research of Jaśkiewicz [7; 8], the tillage method did not have a clear effect on winter triticale yields. They depended mainly on the weather conditions and a cultivar.

It is assumed that triticale cultivars yield differently under changing conditions of crop rotation and soil tillage method.

The aim of this study was to assess the influence of the tillage method on the yields of winter triticale grains, depending on the crop rotation applied.

\section{Materials and methods}

The studies were conducted in the years of 2012/2013, 2014/2015 and 2015/2016 in the ES of the Institute of Soil Science and Plant Cultivation State Research Institute in Pulawy, Poland $\left(51^{\circ} 15^{\prime} \mathrm{N}\right.$, $22^{\circ} 18^{\prime}$ E). The experiment was located on a lessive soil (Luvisol), on plots with the area of $45 \mathrm{~m}^{2}$, in 4 replicates. The soil was characterized by the $\mathrm{pH}$ value similar to neutral (pHKCL 6.5). It contained $17.3 \mathrm{mg} \mathrm{P}_{2} \mathrm{O}_{5}$ and $18.1 \mathrm{mg} \mathrm{K} \mathrm{K}_{2} \mathrm{O}$ in $100 \mathrm{~g}$ of soil and $1.08 \%$ of humus.

The sowing of winter triticale was performer on 25 th September. Triticale was grown in cereal monoculture, i.e. spring barley, in a crop rotation with $75 \%$ share of cereals in the sowing structure after winter wheat. In 2012/2013, triticale was sown in a crop rotation with $50 \%$ share of cereals in the structure after field bean. The first factor of the experiment was the method of tillage - plowing and simplified. The second factor in 2012/2013 were the long-straw winter triticale cultivars Cerber and Fredro, whereas in the growing seasons 2014/2015 and 2015/2016 - Fredro and Alekto (a semidwarf form). The amount of seeds sown was 3.5 million seeds per hectare. Mineral fertilization was applied depending on the soil abundance. Throughout the experiment, full protection of plants against pathogens was carried out.

In autumn, triticale plants had favourable conditions for growth and development (Table 1). In October 2012, rainfall was twice as high as long-term mean. The year of 2013, from January to June, saw much higher rainfall than the year before. The same situation occurred in 2016, except for June, as the rainfall fell by $42.1 \mathrm{~mm}$ compared to the long-term mean. In May 2015 there was by $51 \mathrm{~mm}$ more 
rainfall. The months of July in 2013 and 2015 were exceptionally dry. The growing seasons 2012/2013 and 2015/2016 saw similar total rainfall $(605 \mathrm{~mm}$ and $585 \mathrm{~mm}$ ), whereas a lower amount of rainfall $(383 \mathrm{~mm})$ was recorded in the growing season 2014/2015, deviating from the long-term mean averagely by $25 \%$.

In the years 2012/2013, the average air temperature was close to the long-term mean, while the other two growing seasons were characterized by higher temperatures. Nevertheless, a more optimal layout of temperatures and precipitation was recorded in 2016.

After the harvest, the triticale yield was determined. The obtained results were statistically worked out in the software Statistica, with the method of the analysis of variance ANOVA, and the differences were estimated with Tukey's test at $\alpha=0.05$.

Characteristics of weather conditions

Table 1

\begin{tabular}{|c|c|c|c|c|}
\hline Months & $\mathbf{2 0 1 2 / 2 0 1 3}$ & $\mathbf{2 0 1 4 / 2 0 1 5}$ & $\mathbf{2 0 1 5} / \mathbf{2 0 1 6}$ & Multiplicity \\
\hline \multicolumn{5}{|c|}{ Temperature, ${ }^{\mathbf{O}} \mathbf{C}$} \\
\hline September & 15.0 & 15.1 & 15.3 & 13.3 \\
\hline October & 8.3 & 10.1 & 7.3 & 8.0 \\
\hline November & 5.5 & 4.9 & 5.2 & 2.8 \\
\hline December & -3.3 & 0.6 & 4.0 & -1.3 \\
\hline January & -3.4 & 1.2 & -3.3 & -3.3 \\
\hline February & -0.6 & 1.0 & 3.7 & -2.3 \\
\hline March & -1.6 & 4.1 & 4.3 & 1.6 \\
\hline April & 8.8 & 8.6 & 9.6 & 7.8 \\
\hline May & 15.5 & 13.9 & 15.6 & 13.5 \\
\hline June & 18.9 & 17.9 & 19.8 & 16.8 \\
\hline July & 18.7 & 20.4 & 20.1 & 18.5 \\
\hline \multicolumn{7}{|c|}{ Rainfalls, mm } & 118 & 51 \\
\hline September & 21 & 12 & 27 & 43 \\
\hline October & 81 & 22 & 38 & 39 \\
\hline November & 29 & 21 & 27 & 37 \\
\hline December & 31 & 36 & 33 & 31 \\
\hline January & 61 & 43 & 64 & 30 \\
\hline February & 41 & 5 & 53 & 30 \\
\hline March & 50 & 21 & 38 & 40 \\
\hline April & 46 & 28 & 72 & 57 \\
\hline May & 103 & 108 & 28 & 70 \\
\hline June & 94 & 32 & 87 & 84 \\
\hline July & 48 & 55 & & \\
\hline
\end{tabular}

\section{Results and discussion}

No significant difference was found between winter triticale grain yields in 2015 and 2016, but such a difference occurred between 2015 and 2013. Weather conditions during the growing period had an impact on triticale grain yield. The year 2013 saw high rainfall during the triticale flowering period. Under $75 \%$ share of cereals in the crop rotation, triticale yielded lower by $36 \%$ compared to 2016 , under the same crop rotation (Fig. 1A, 1B). According to other studies [9; 10], both shortages and excess of precipitation result in yield decrease. Moderate autumn drought in the growing season $2014 / 2015$ was favourable for the growth of the root system and spring vigour of plants. Optimum rainfall from April to June in 2015 and 2016 positively translated into triticale grain yield. Favourable weather conditions in the period of the formation of shoots (in 2015 and 2016) and grains (in 2016) contributed to an increase in winter triticale grain yield under $75 \%$ share of cereals in the crop rotation (Fig. 1B). In the analyzed two-year period, the yield level of winter triticale did not depend on the cultivation system (Fig. 1B). 
A)

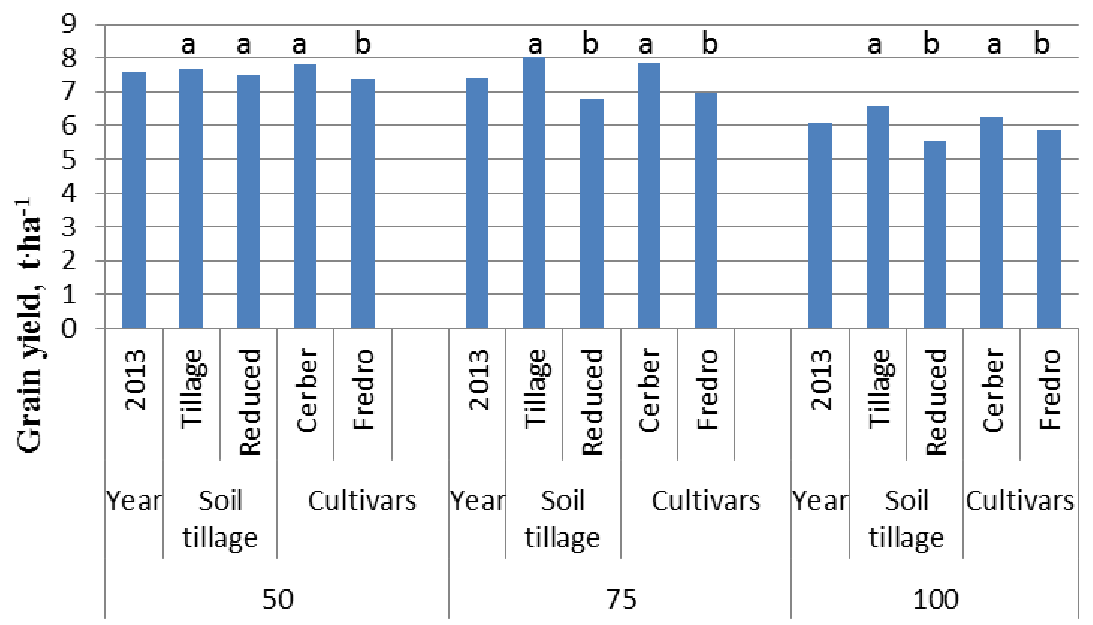

B)

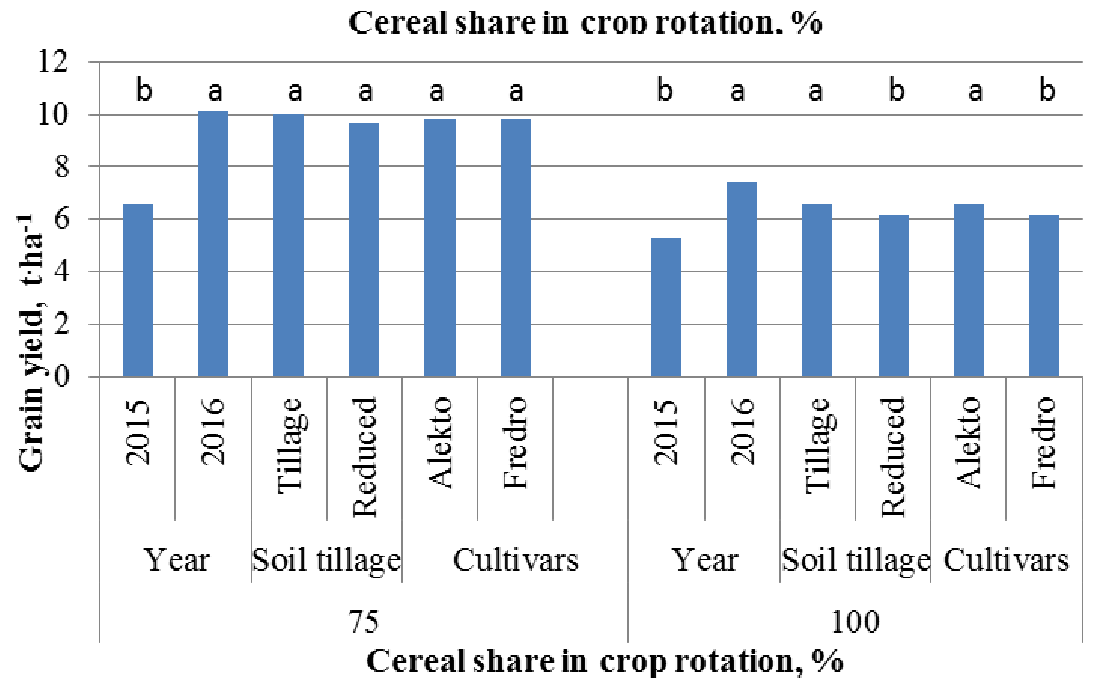

Fig. 1. Triticale yields $\left(t \cdot h^{-1}\right)$ depending on soil tillage, genetic factor, and crop rotation in 2013

(A) and 2015-2016 (B): a, b - mean with the same letter in columns are not significantly different

However, in 2013, under $75 \%$ and $100 \%$ share of cereals in crop rotation, the plow cultivation system and cultivar Cerber had significantly highest grain yields (Fig. 1A). The grain yield of Cerber was by $13 \%$ higher in comparison with cv. Fredro under $75 \%$ share of cereals in the crop rotation and by $7 \%$ under cereal monoculture. In 2013, under $75 \%$ and $100 \%$ share of cereals in crop rotation, in the simplified cultivation conditions, triticale yields were by $14-15 \%$ lower compared to the plow system.

The research by Starczewski et al. [11] shows that surface cultivation reduces the yield of winter triticale grain. Another scientific study [6] showed that the weather in the years of research during the growing season had a greater influence on the productivity of winter triticale than the simplifications in the soil tillage. In the research, Jaśkiewicz [7] and Pabina et al. [12], the greatest influence on the triticale yields was exerted by drought during the growing season, regardless of the cultivation procedures carried out. German scientific studies show that triticale yielded similarly in both tillage systems.

In 2013, an interaction between the tillage methods and winter triticale cultivars was found (Table 2). Under $50 \%$ and $75 \%$ shares of cereals in the crop rotation, a significantly higher yield was observed for cv. Cerber in plough cultivation conditions, and for cv. Fredro in simplified cultivation. In the two-year period with $100 \%$ share of cereals in the crop rotation, cv. Alekto yielded significantly higher (Table 3). Under plough cultivation, the grain yield of this cultivar was by $0.75 \mathrm{t} \cdot \mathrm{ha}^{-1}$ higher than the yield of cv. Fredro obtained in simplified cultivation (Table 3 ). In general, triticale cultivars Alekto and Ceber yielded better in simplified cultivation than Fredro plants, which resulted in their higher yields. 
In winter triticale, there were correlations between the tillage methods and cultivars (cereal monoculture) (Table 3), as well as between years and tillage methods, years and cultivars (75\% share of cereals in crop rotation) (Table 4). In 2016, triticale cv. Alekto yielded by $0,42 \mathrm{t} \cdot \mathrm{ha}^{-1}$ higher than $\mathrm{cv}$. Fredro and by $1.01 \mathrm{t} \cdot \mathrm{ha}^{-1}$ higher than $\mathrm{cv}$. Fredro in 2015 (Table 3). In 2016, the winter triticale grain yield was higher by $0.86 \mathrm{t} \cdot \mathrm{ha}^{-1}$ and by $0.89 \mathrm{t} \cdot \mathrm{ha}^{-1}$ in comparison to under plough cultivation. In 2016, which saw more even rainfall than the previous years, triticale plants had favorable moisture conditions, used nutrients contained in the soil, and performed better under ploughing than under simplified cultivation. In 2015, triticale yielded similarly under plough and simplified cultivation. In contrast, under cereal monoculture in 2015 and plough cultivation system, the grain yield of winter triticale was by $15 \%$ higher than in the case of simplified triticale, and on average by $50 \%$ higher than in 2016 (Table 4).

In other studies, conducted by Jaśkiewicz [7] in 2010/2011 and 2013/2014 with winter triticale cultivars Pizarro and Pigmej, sown in a good site under optimal rainfall, higher grain yields were obtained in the plough cultivation conditions. On the other hand, in the case of moderate rainfall deficit, the plants performed better under simplified cultivation. As for cereal monoculture, the tillage systems did not differentiate the yield of winter triticale cultivars. In the crop rotation with $100 \%$ share of cereals, the tillage method did not significantly affect the grain yield of the cultivars [7]. In the study of Małecka et al. [13], triticale cv. Fidelio yielded lower when it was cultivated without plough than when cultivated with plough. In the conditions of simplified cultivation, the winter triticale grain yield was lower by $24 \%$ in comparison with plough tillage. Other scientific papers [3; $10 ; 14 ; 15]$ showed a decrease in cereal yields, including triticale, in the conditions of cereal monoculture under ploughless cultivation. On the other hand, Kelley and Sweeney [16] found a slight decrease in triticale yield under simplified tillage.

Table 2

Interaction of grain yield $\left(t \cdot h^{-1}\right)$ between the method of soil tillage and a genetic factor depending on crop rotation in 2013 harvest year

\begin{tabular}{|c|c|c|c|c|}
\hline \multirow{4}{*}{ Cultivars } & \multicolumn{4}{|c|}{ Cereal share in crop rotation, $\%$} \\
\hline & \multicolumn{2}{|c|}{50} & \multicolumn{2}{|c|}{75} \\
\hline & \multicolumn{4}{|c|}{ Method of soil tillage } \\
\hline & Tillage & Reduced & Tillage & Reduced \\
\hline Cerber & $7.79 \mathrm{a}$ & $7.87 \mathrm{a}$ & $8.31 \mathrm{a}$ & $7.43 \mathrm{ab}$ \\
\hline Fredro & $7.56 \mathrm{ab}$ & $7.14 \mathrm{~b}$ & $7.75 \mathrm{ab}$ & $6.15 \mathrm{~b}$ \\
\hline
\end{tabular}

$\mathrm{a}, \mathrm{b}-$ mean with the same letter in columns are not significantly different

Table 3

Interaction of grain yield $\left(\mathrm{t} \cdot \mathrm{ha}^{-1}\right)$ between genetic factors and the harvest year and a tillage system in 2015 and 2016 harvest year depending on crop rotation

\begin{tabular}{|l|c|c|c|c|}
\hline \multirow{3}{*}{ Cultivars } & \multicolumn{3}{|c|}{ Cereal share in crop rotation, \% } \\
\cline { 2 - 5 } & \multicolumn{2}{|c|}{75} & \multicolumn{2}{c|}{100} \\
\cline { 2 - 5 } & \multicolumn{2}{|c|}{ Year of harvest } & Metod of soil tillage \\
\cline { 2 - 5 } & 2015 & 2016 & Tillage & Reduced \\
\hline Alekto & $9.79 \mathrm{~b}$ & $10.31 \mathrm{a}$ & $6.78 \mathrm{a}$ & $6.30 \mathrm{ab}$ \\
\hline Fredro & $9.30 \mathrm{c}$ & $9.89 \mathrm{ab}$ & $6.32 \mathrm{ab}$ & $6.03 \mathrm{~b}$ \\
\hline
\end{tabular}

$\mathrm{a}, \mathrm{b}-$ mean with the same letter in columns are not significantly different

Table 4

Interaction of grain yield $\left(\mathrm{t} \cdot \mathrm{ha}^{-1}\right)$ between the harvest year and tillage system depending on crop rotation

\begin{tabular}{|c|c|c|c|c|}
\hline \multirow{4}{*}{ Metod of soil tillage } & \multicolumn{4}{|c|}{ Cereal share in crop rotation, $\%$} \\
\hline & \multicolumn{2}{|c|}{75} & \multicolumn{2}{|c|}{100} \\
\hline & \multicolumn{4}{|c|}{ Year of harvest } \\
\hline & 2015 & 2016 & 2015 & 2016 \\
\hline Tillage & $9.56 \mathrm{~b}$ & $10.42 \mathrm{a}$ & $7.95 \mathrm{a}$ & $5.15 \mathrm{c}$ \\
\hline Reduced & $9.53 \mathrm{~b}$ & $9.78 \mathrm{~b}$ & $6.92 \mathrm{~b}$ & $5.41 \mathrm{c}$ \\
\hline
\end{tabular}

$\mathrm{a}, \mathrm{b}-$ mean with the same letter in columns are not significantly different 


\section{Conclusions}

1. The yield level was influenced by the genetic factor, method of tillage, crop rotation, and weather.

2. Under optimal rainfall, higher yields of winter triticale grain were obtained under ploughing. The grain yield was higher by $15 \%$ compared to the simplified cultivation.

3. In the crop rotation with a small percentage of cereals, the highest level of triticale yields was recorded (mean $8.6 \mathrm{t} \cdot \mathrm{ha}^{-1}$ ), while lower triticale yields were obtained by $2.34 \mathrm{t} \cdot \mathrm{ha}^{-1}$ in the crop rotation with a large percentage of cereals.

4. In plough cultivation conditions cvs. Cerber and Alekto showed higher yields (8.31 and $\left.6.78 \mathrm{t} \cdot \mathrm{ha}^{-1}\right)$, whereas in simplified cultivation lower grain yield was for $\left(6.09 \mathrm{t} \cdot \mathrm{ha}^{-1}\right) \mathrm{cv}$. Fredro.

5. Grain monoculture contributed to lowering the level of winter triticale yield.

\section{References}

[1] Lal R., Reicosky D.C. Hanson J.D. Evolution of the plow over 10,000 years and the rationale for no-till farming. Soil Tillage Research, 93(1), 2007, pp. 1-12.

[2] Smagacz J. Produkcyjno-ekonomiczne i środowiskowe skutki różnych systemów uprawy (Production, economical, and environmental effects of different cultivation systems). Studia i Raporty: Studies and Reports of IUNG-PIB, Puławy, Poland. 29(3), 2012, pp. 121-134 (in Polish).

[3] Smagacz J. Konsekwencje organizacyjne i środowiskowe różnych systemów uprawy (Organizational and environmental consequences of different cultivation systems). Studia i Raporty: Studies and Reports IUNG-PIB, Puławy, Poland 47(1), 2016, pp. 139-153 (in Polish).

[4] Kornmann M., K?ller K. Ecological and economical effects of different tillage systems. Fragmenta Agronomica, 2, 1997, pp. 391-394 (in Polish).

[5] Małecka I., Blecharczyk A. Reakcja pszenżyta ozimego na systemy uprawy roli (Response of winter triticale to different tillage systems). Folia Universitatis Stetinensis, Agricultura, 228(91), 2002, pp. 81-86 (in Polish).

[6] Starczewski J., Czarnocki S., Wielogórski G. Wpływ przedsiewnej uprawy roli na architekturę łanu i plonowanie pszenżyta ozimego (The impact of pre-sowing soil cultivation on the field architecture and yields of winter triticale). Folia Universitatis Stetinensis, Agricultura, 247 (100), 2006, 179-186 (in Polish).

[7] Jaśkiewicz B. Yield of some winter triticale cultivars as affected by the tillage system. Acta Scientarum Polonorum, Agricultura, 15(1), 2016, pp.17-27 (in Polish).

[8] Jaśkiewicz B., Szczepanek M. Crop management and cultivar have influence on alkylresolcinol content in triticale grain. Acta Agriculturae Scandinavica, Section B- Soil Plant Science, 66(7), 2016, pp.570-574. DOI.org/10.1080/09064710.2016.1201139

[9] Chmura K., Chylińska E., Dmowski Z., Nowak L. Role of the water factor in yield formation of chosen field Crops. Infrastructure and Ecology of Rural Areas. Polska Akademia Nauk: Polish Academy of Sciences, Cracow, 9, 2009, pp. 33-44.

[10] Weber R., Hryńczuk B. Plon i komponenty plonu pszenżyta w zależności od sposobu uprawy roli po wieloletnim odłogu (Yield and components of triticale yield depending on the method of cultivation after many years of fallow). Fragmenta Agronomica, 2(94), 2007, pp. 381-389 (in Polish).

[11] Starczewski J., Czarnocki Sz., Turska E. Alternatywne sposoby uprawy roli i ich ekonomiczna ocena (Alternative farming methods and their economic evaluation). Annales UMCS, Sec. E., Agricultura, 59, 2004, pp. 277-284 (in Polish).

[12] Pabin J., Włodek S., Biskupski A. Niektóre uwarunkowania środowiskowe i produkcyjne przy stosowaniu uproszczonych sposobów uprawy roli (Selected environmental and production conditions under the use of simplified farming methods). Inżynieria Rolnicza: Agricultural Engineering, 1(99), 2008, pp. 333-338 (in Polish).

[13] Małecka I., Blecharczyk A., Sawinska Z. Piechota T., Waniorek B. Plonowanie zbóż w zależności od sposobów uprawy roli (Harvesting of cereals depending on a farming method used). Fragmenta Agronomica, 29(1), 2012, pp.114-123 (in Polish).

[14] Blecharczyk A., Śpitalniak J., Małecka I. Wpływ doboru przedplonów oraz systemów uprawy roli i nawożenia azotem na plonowanie pszenicy ozimej. (The influence of the selection of forecrops, 
tillage system, and nitrogen fertilization on yields of winter wheat). Fragmenta Agronomica, 23(2), 2006, pp. 273-286 (in Polish).

[15] Parylak D., Pytlarz E. Skutki produkcyjne monokultury pszenicy ozimej w warunkach upraszczania uprawy roli (The production effects of winter wheat monoculture in the conditions of simplification of soil cultivation). Fragmenta Agronomica, 30(4), 2013, pp. 114-121 (in Polish).

[16] Kelley K. W., Sweeney D.W. Tillage and urea ammonium nitrate fertilizer rate and placement affects winter wheat following grain sorghum and soybean. Agronomy Journal, 97, 2005, pp. 690-697. 